\title{
The Compositions of Thomas Tallis: How the English Reformation Informed His Style
}

Joshua L. Gore

Cedarville University, joshualgore@cedarville.edu

Follow this and additional works at: https://digitalcommons.cedarville.edu/musicalofferings

Part of the Fine Arts Commons, Musicology Commons, and the Music Theory Commons

DigitalCommons@Cedarville provides a publication platform for fully open access journals, which means that all articles are available on the Internet to all users immediately upon publication. However, the opinions and sentiments expressed by the authors of articles published in our journals do not necessarily indicate the endorsement or reflect the views of DigitalCommons@Cedarville, the Centennial Library, or Cedarville University and its employees. The authors are solely responsible for the content of their work. Please address questions to dc@cedarville.edu.

\section{Recommended Citation}

Gore, Joshua L. (2020) "The Compositions of Thomas Tallis: How the English Reformation Informed His Style," Musical Offerings: Vol. 11 : No. 2 , Article 1.

DOI: 10.15385/jmo.2020.11.2.1

Available at: https://digitalcommons.cedarville.edu/musicalofferings/vol11/iss2/1 


\title{
The Compositions of Thomas Tallis: How the English Reformation Informed His Style
}

\author{
Document Type \\ Article
}

\begin{abstract}
Thomas Tallis, known by some as the "Father of English Church Music," accomplished one of the most impressive feats in the history of musical service: surviving in the Chapel Royal through the reigns of vastly different monarchs during one of the most volatile political climates in the country's history. A clear streak of pragmatism shines through this stability and success, but exactly how did that pragmatism demonstrate itself within his compositional style? Through exploration and analysis of Tallis's musical style in different political and religious periods, one discovers the answer to how he managed to navigate the winds of change that led to ostracization and demise for so many leaders in the flux of power. His brilliance becomes evident as the diversity and skill with which he composed allowed the music to speak to its audience in a way that was both politically acceptable and stylistically creative. Through his adaptability and keen sense, Tallis's compositions became exemplars for the musical principles espoused in whatever period he composed within, whether it be the austere practice of the Cranmer/ Edwardian period, or the decidedly more expressive works composed under Queen Mary. The fact that his music still speaks to many today shows the legacy that this titan of church composition left behind as the nimble purveyor of distinct and period defining styles in composition.
\end{abstract}

\section{Keywords}

Tallis, Thomas Tallis, Renaissance, England, English Reformation, Polyphony, Protestantism, King Edward VI, Queen Mary, King Henry VIII

\section{Creative Commons License}

\section{c) (i) $(9)$}

This work is licensed under a Creative Commons Attribution-Noncommercial-No Derivative Works 4.0 License. 


\title{
The Compositions of Thomas Tallis: How the English Reformation Informed His Style
}

\author{
Joshua L. Gore \\ Cedarville University
}

$\mathrm{W}$

ithin the blink of eye, significant change can sweep through a nation. This was the case in England during its religious reformation of the sixteenth century, a period of redefining the church, the state, and the people inhabiting both. With these winds of change came many questions. One of the key questions asked by the reformers in England centered around the role of music in the liturgy of the newly formed Anglican Church. To answer this difficult question, the reformers sought to uphold the value of Sola scriptura, or scripture alone. ${ }^{1}$ This principle, although well defined, lacked clarity in determining what constituted legitimate musical expression in church because of scripture's lack of much discussion on the topic. While the reformers were busy arguing over the particulars of music philosophy and aesthetics, it became incumbent upon composers of this era to put the espoused reformation principles into action within their musical compositions. One key musical figure in this period was Thomas Tallis. As a member of the Chapel Royal for over four decades, his musical career saw the reign of vastly different monarchs whose religious and musical principles varied widely. ${ }^{2}$ Because of the constantly shifting religious structures in the country, Tallis's music had to fulfill many roles while undergoing seismic changes throughout the entirety of his career. As a result of tumultuous political and religious movements,

\footnotetext{
${ }^{1}$ Jonathan Willis, Church Music and Protestantism in Post-Reformation England: Discourses, Sites and Identities, St. Andrews Studies in Reformation History (Burlington, VT: Ashgate, 2010), 40.

${ }^{2}$ Clayton Wilson Henderson Jr., "The Effects of the English Reformation on Music as Seen in the Church Music of Thomas Tallis" (master's thesis, Ohio University, 1960), 20.
}

Musical Offerings 11, no. 2 (2020): 45-58 ISSN 2330-8206 (print); ISSN 2167-3799 (online)

(C) 2020, Joshua L. Gore, licensed under CC BY-NC-ND (http://creativecommons.org/licenses/by-nc-nd/4.0/) 
Thomas Tallis's evolution in style reflects the changing values in sixteenth-century England.

While the religious reformations sweeping Europe shared many common characteristics, the reformers held a wide variety of views surrounding the role of music in church. As the Protestant Reformation spread, many leaders came to be influential in developing different denominations. Each of these theologians developed theologies that matched their own interpretation of scripture, a key rational principle established by Luther in the infancy of the Reformation. ${ }^{3}$ While key differences were expressed by the reformers, many similarities in belief emerged as a result of the shared principles of the Reformation such as Sola scriptura. ${ }^{4}$ One common belief about sacred music in this period was that liturgical music needed to reflect restraint. ${ }^{5}$ Both Calvin and Luther sought to minimize the excesses that had emerged in florid polyphonic music. ${ }^{6}$ While the Calvinistic and Lutheran churches created forms of musical expression that reflected this principle, the newly founded Anglican Church lacked clarity in charting a musical course of its own, largely due to the fealty to the Latin liturgy and Catholic doctrine that was demonstrated by King Henry VIII. ${ }^{7}$ It was only the ascension of Edward VI to the throne that would give Protestant reformers the chance to enact musical reforms in the Anglican Church. ${ }^{8}$

With the ascension of the boy king Edward VI to the throne, the English reformers acting as Edward's regents had the power to set the standards for the liturgy of the new Anglican Church without contending with the political motivations of King Henry VIII. ${ }^{9}$ In the beginning of the English Reformation, the decidedly political circumstances under which the schism occurred had allowed Catholic doctrine to remain largely untouched..$^{10}$ One evidence of this was the maintenance of Catholic liturgy in the church, a liturgy that was to be restored during the reign of Queen Mary after the death of King Edward VI. ${ }^{11}$ This liturgy, serving

\footnotetext{
${ }^{3}$ J. Peter Burkholder, Donald Jay Grout, and Claude V. Palisca, A History of Western Music, $9^{\text {th }}$ ed. (New York, W. W. Norton, 2014), 215.

${ }^{4}$ Willis, Church Music, 40.

5 Ibid., 51.

${ }^{6}$ Ibid., 39.

${ }^{7}$ Burkholder, Western Music, 223-224.

${ }^{8}$ Ibid.

${ }^{9}$ Ibid., 223.

${ }^{10}$ Ibid.

${ }^{11}$ Willis, Church Music, 55.
} 
as the backbone of the Latin rite, would continue to be used until the death of King Henry in $1547 .{ }^{12}$ With Edward on the throne, the English reformers would consolidate their power to shape the Anglican Church and consequently, the music composed therein. ${ }^{13}$

One Anglican musical reform that reflected the wider Reformation was the belief that florid polyphony was a superfluity in Catholic music that needed to be "cleansed from the Church."14 This view reflected Luther and Calvin's own musical leanings and would later be championed by the Archbishop of Canterbury, Thomas Cranmer. ${ }^{15}$ Arguably the most important development in Anglican music was the abolition of the Latin liturgy, and the establishment of an English litany. ${ }^{16}$ This English litany took the Latin mass texts and translated them into English. ${ }^{17}$ While the content remained unchanged, the vernacular language allowed the average parishioner to understand and affirm truths of the faith. Another significant reform that reflected Cranmer's views was the institution of restrictions on melismatic writing in choral music. With King Edward's ascension to the throne, syllabic writing became the law for church music, and composers were no longer free to write how they saw fit. ${ }^{18}$ With these new principles in place, those composing for the purposes of Church worship had to find an artistic voice within the given parameters.

The bulk of Tallis's compositional career took place during the political and social unrest that punctuated the English Reformation. While the cultural and religious fires of the period raged, Tallis found himself in the crossfire of constantly changing values and leadership. While little is known about his early professional life, some of Tallis's career movements can be traced through documentation from the period. His first documented position was as an organ player and cantor at Dover Priory for a short period of time in the early 1530s. ${ }^{19}$ Tallis's next confirmed appointment was at Waltham Abbey in $1540 .{ }^{20}$ Waltham Abbey was later dissolved during a period of closures in Catholic

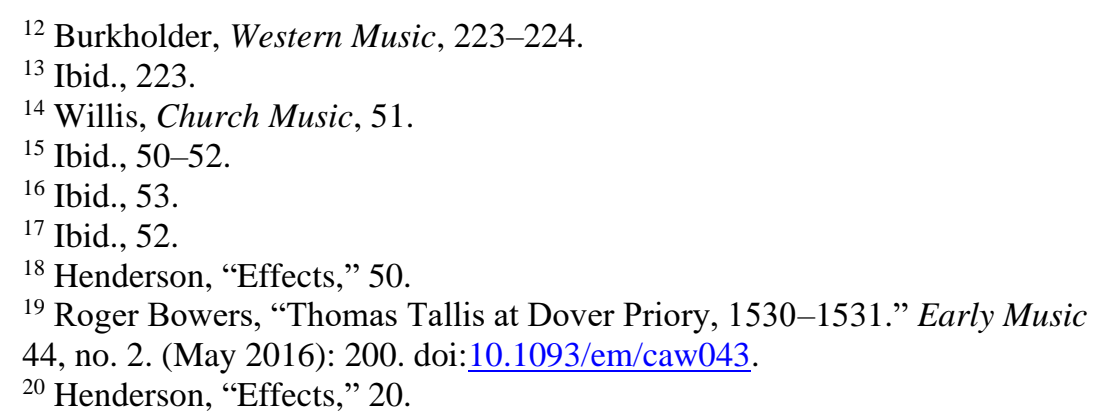


institutions that saw over 800 smaller monasteries close between the years 1536 and 1540, leaving Tallis without employment. ${ }^{21}$ While Tallis was quite mobile in his early professional years, he would soon find stable employment in the most prestigious musical institution in England: the Chapel Royal. ${ }^{22}$ It is probable that his appointment to the Chapel Royal was assisted by King Henry VIII, who likely noticed Tallis during his frequent visits to Waltham Abbey before its dissolution. ${ }^{23}$ With his role as a royal composer, Tallis would begin the longest and most politically challenging portion of his career, with his tenure lasting from around 1542 to the mid-1570s. ${ }^{24}$ Because of the length of his tenure and the number of monarchs he served, Tallis's works were widely diverse in function, as Tallis wrote for both Protestant and Catholic religious services. It is this diversity in composition that earned Tallis the nickname, the "Father of English Church Music." 25 Because of this title, it is necessary to explore how Tallis's music adapted to the needs and demands of the different royal periods.

While Tallis's career in the Chapel Royal began under the reign of King Henry, it was not until the reforms of King Edward's reign that Tallis's music reflected distinct changes in English liturgical music. Because of the zealous actions of the Protestant reformers after the death of King Henry VIII, Tallis was forced to contend with many significant changes in standard practice for church composition. ${ }^{26}$ One emerging genre that reflected the new practices in composition was the English anthem. Distinct from the Latin motets of contemporary Catholic composers, English anthems were restrained works written for the Anglican Church that were set with English texts. ${ }^{27}$ Tallis's anthems typified the genre, showing acute political and religious sense and a careful attention to detail.

One work that perfectly captures the spirit of reformation within the Anglican Church is Tallis's anthem $O$ Lord Give Thy Holy Spirit. The most obvious and distinct feature of the work is that the text is in

\footnotetext{
${ }^{21}$ Andrew Gant, O Sing Unto the Lord: A History of English Church Music

(Chicago: University of Chicago Press, 2017), 73.

${ }^{22}$ Henderson, "Effects," 20.

${ }^{23}$ Ibid.

${ }^{24}$ Ibid.

25 Ibid., 23-24.

${ }^{26}$ Burkholder, Western Music, 223-224.

${ }^{27}$ Ibid., 224.
} 
English. ${ }^{28}$ Because of the rich and storied tradition of English sacred music, it is easy to forget how novel the use of English text was in sacred works during this time period. English sacred music expert Andrew Gant goes as far as to say that using English in this context was "revolutionary." 29 While English text was, in fact, a significant change, it is necessary to remember that it was in service to the reigning political and religious ideals of the day. Not only was language a significant point, but the sheer restraint with which this piece was composed also reveals the ideological leanings behind it. This restraint shows clearly in the number of voices utilized by Tallis. In an era where it was increasingly common to have five or more voices in a sacred choral work such as this, this setting only has four carefully balanced parts. ${ }^{30}$ The language and number of voices are only the beginnings of the piece's Reformation influenced structure.

The main musical elements that typify this work within the Edwardian period involve the textures utilized by Tallis. The opening section from $\mathrm{mm}$. 1-4 is set in a homophonic texture, with polyphony beginning in $\mathrm{m}$. 5 (Examples 1 and 2). ${ }^{31}$ While homophony commonly alternated with polyphonic passages in Catholic works of this period, the element that distinguishes this homophony is the clear syllabic setting of the words, allowing for declamation of text that could be understood by parishioners. This feature distinctly follows the orthodoxy of the day that was advanced through the efforts of men like Thomas Cranmer.

Example 1: $O$ Lord Give Thy Holy Spirit, mm. 1-3. ${ }^{32}$

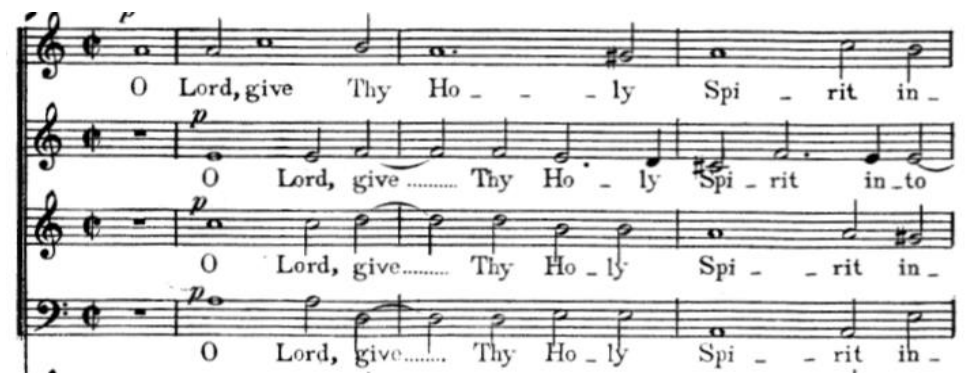

${ }^{28}$ Thomas Tallis, O Lord Give Thy Holy Spirit (London: Novello, 1899), 2-4. https://imslp.org/wiki/O_Lord\%2C_Give_Thy_Holy_Spirit_(Tallis\%2C

Thomas).

${ }^{29}$ Gant, $O$ Sing, 103.

${ }^{30}$ Tallis, O Lord, 2.

${ }^{31}$ Ibid., 2.

32 Ibid. 
Another important feature of this work that demonstrates its restraint is Tallis's treatment of polyphony. The first polyphonic passage begins in m. 5 (Example 2) with "and lighten our understanding," and quickly displays the importance of continuing textual clarity even in polyphonic textures. ${ }^{33}$ With quick successive entrances in the soprano, alto, and bass in $\mathrm{mm}$. 5-6, the text is never truly lost as each entrance is distinct. ${ }^{34}$ Another way that Tallis keeps the text clear in this section is by entering with two voices in homophonic texture in the soprano and alto at m. $5 .{ }^{35}$

Example 2: $O$ Lord Give Thy Holy Spirit, mm. 4-7. ${ }^{36}$

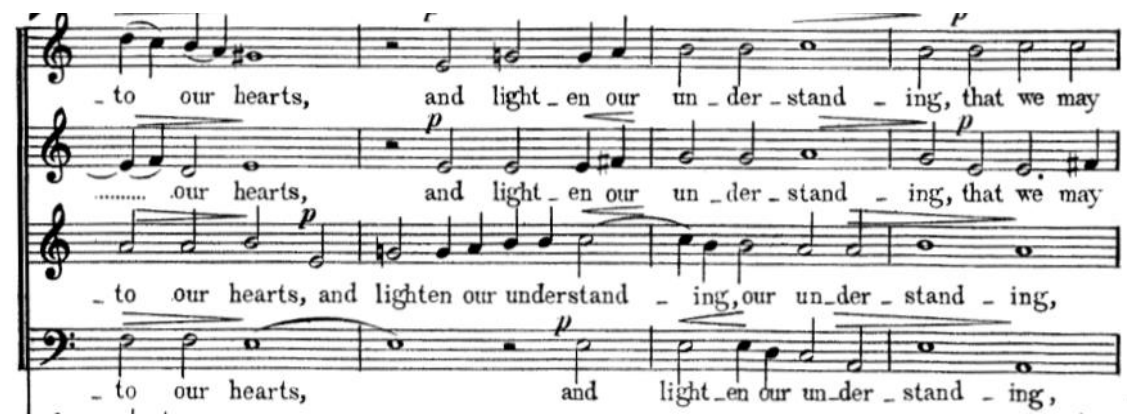

Although this technique is utilized in Catholic works as well, its presence in a four-part texture rather than a fuller texture causes it to bring out the text more distinctly. One final technique that Tallis uses to ensure the clarity of text through texture is the use of full cadences rather than elided cadences. To achieve these cadences, Tallis pulls back the polyphonic texture and causes the voices to return together in a strong and unified fashion (Example 3). These kinds of cadences occur frequently in this work, in mm. 12, 16, 24, and 27. ${ }^{37}$

\footnotetext{
${ }^{33}$ Tallis, O Lord, 2.

${ }^{34}$ Ibid.

${ }^{35}$ Ibid.

36 Ibid.

${ }^{37}$ Ibid., 3-4.
} 
Example 3: $O$ Lord Give Thy Holy Spirit, mm. 12-13. ${ }^{38}$

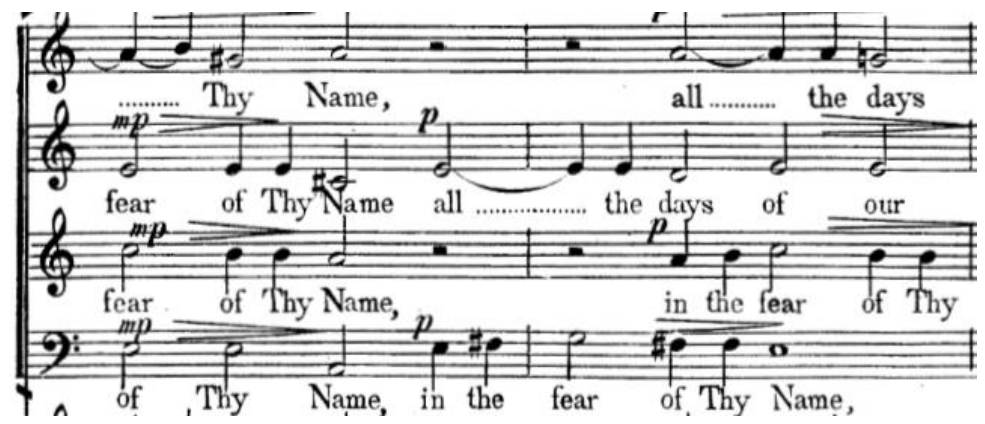

These elements combine to make the text of utmost importance, and to fulfill the mandates required by the government and religious forces. Through clear, intentionally restrained writing, Tallis demonstrates his fealty to the system that he served under in the Chapel Royal during this period.

While $O$ Lord Give Thy Holy Spirit is a good example of the Edwardian style, Tallis's collective body of work in this period demonstrates his awareness of the prevailing religious ideals of the day. Though lesser known, Tallis's Anglican Service compositions from this period were also reflective of the reformation principles undergirding the English Church..$^{39}$ One specific work, known as the Dorian Service, represents well the continuity in style between Tallis's anthems and other works in the liturgy. Utilizing an English translation of the Latin mass texts, this work contains similar textual and textural treatment as O Lord Give Thy Holy Spirit. ${ }^{40}$ One Tallis scholar, Clayton Wilson Henderson Jr., describes the style of the work in blunt terms, saying, "With but few exceptions, and those confined mostly to the inner voices at cadence points, the style of Tallis' Dorian Service is severely homophonic and syllabic in following the principle set forth by Cranmer." ${ }^{41}$ Rather than diverging from the norms of style established in the English anthem, Tallis's style in liturgical music more strongly confirmed the prevailing currents found in his work from this period. While the restrictive guidelines imposed on church musicians during this time were well

\footnotetext{
${ }^{38}$ Tallis, $O$ Lord, 3.

${ }^{39}$ Henderson, "Effects," 50-55.

40 Ibid.

${ }^{41}$ Ibid., 54.
} 
followed by Tallis and informed his style, this reality would quickly change as King Edward's health declined.

With the death of King Edward, a new monarch representing an entirely different set of religious values would ascend the throne in England. This new monarch was Queen Mary, the sister of King Edward and daughter to the late King Henry. ${ }^{42}$ Queen Mary wasted little time in restoring the country to its Catholic roots. Mary began her rule of England in July of 1553 and had restored the Catholic mass in the country by September. ${ }^{43}$ By 1554, the formal schism between England and the Pope had been resolved, and all anti-papacy legislation was repealed. ${ }^{44}$ One action taken by Mary that had far reaching consequences was the reinstatement of heresy legislation that had previously been repealed. ${ }^{45}$ With the crackdown on Protestant practice came one of the violent events of this new rule, the burning at the stake of Archbishop Thomas Cranmer, the man largely responsible for many of the musical principles that guided Tallis during the reign of Edward ${ }^{46}$ With Catholicism gloriously restored and one of its chief opponents removed, the musical implications of the period would begin to be felt.

While Tallis's style was well-polished in the Edwardian period, the dissolution of Reformation principles that had once guided his composition allowed him greater freedom and caused his music to reflect the changing values in England. No longer was restraint a concern, as Cranmer's edicts passed with the accession of the new monarch. Despite the important shift in musical elements during this period, some of the most notable changes that occurred in Tallis's music center around the content and language of his pieces. As was the standard practice before the Protestant Reformation, Tallis began writing in Latin again, marking a departure from the revolutionary English text setting that had defined many of his previous compositions. This change was so notable that scholar John Harley titled an entire chapter of his biography of Tallis "The Reign of Mary I: Music with Latin Words." ${ }^{\text {"In }}$ In addition to Latin texts reappearing, Tallis began to utilize Marian subject matter that had been previously shunned by the Protestant reformers. ${ }^{48}$ One of his most

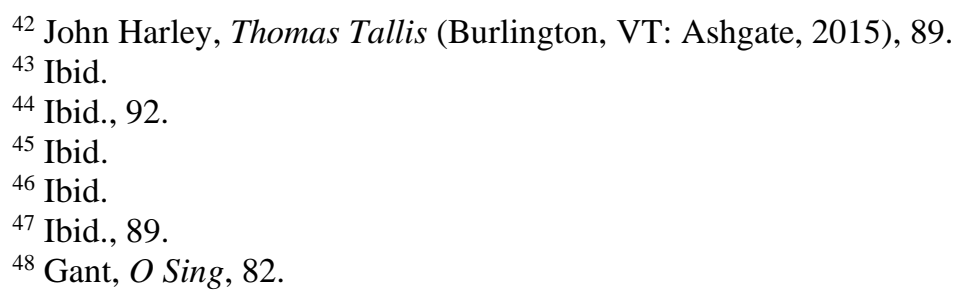


well respected and acclaimed works, Gaude gloriosa mater, believed to have been composed during this period, unapologetically praises the Virgin Mary and serves as an indicator of the shift in religious values that occurred between the reigns of King Edward and Queen Mary. ${ }^{49}$ As Gant says in his history of English Church Music, "The Virgin Mary is back where she belongs, at the heart of music and worship." ${ }^{50}$ While the language and content of Tallis's sacred music in this time reflect the shift away from the accessibility and restraint of Protestant worship, Tallis's musical elements demonstrate most clearly the monumental shift in musical thought.

Tallis's musical writing during Queen Mary's reign represents a return to the well-established style of Catholic composition with expression and exuberance being key features. Tallis's mass Missa puer natus, also known as his Christmas Mass, typifies many of the musical elements that had shifted from his earlier anthem and Service compositions. The first and most notable change that occurs in style between his Dorian Service and Missa puer natus is the change in number of voices from four to seven. ${ }^{51}$ The increase in number of voices immediately leads to potential for obscurity in text and line, a grave offense under the rules of the previous system. One example of textual obscurity as a result of voicing occurs in m. 13 of the "Gloria," as each voice carries distinct syllables and text from the other voices for the first four quarter notes of the measure (Example 4). ${ }^{52}$

\footnotetext{
${ }^{49}$ Gant, $O$ Sing, 93.

${ }^{50}$ Ibid.

${ }^{51}$ Thomas Tallis, Missa puer natus (Gervais Frykman, 2019), 3. https://imslp.org/wiki/Mass_Puer_Natus_(Tallis\%2C Thomas).

${ }^{52}$ Ibid., 4.
} 
Example 4: Missa puer natus, "Gloria," mm. 12-14. ${ }^{53}$

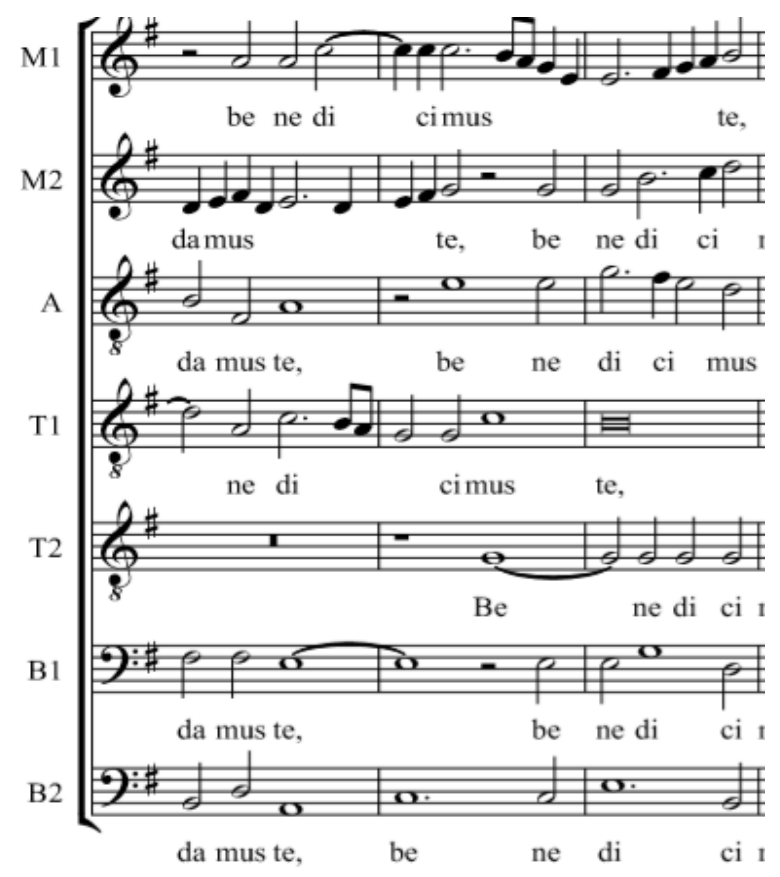

Passages like these appear throughout the score in each movement and punctuate the newfound freedom that was allowed under the new era of composition. Besides allowing for the obscurity of the text through the number of voices, Tallis used these many voices for other expressive purposes. The major way he utilized the voices was to create a thick, polyphonic texture that would have been out of place in an English anthem. One section containing imitative polyphony comes in $\mathrm{mm}$. 2329 of the "Agnus Dei" (Example 5). ${ }^{54}$ To illustrate the collective cry for God's mercy in the text "miserere nobis," Tallis uses imitative polyphony with many quick entrances, weaving a tapestry of sound that would be far too indistinguishable for the practitioner of Anglican Service music. In contrast to the interdependent lines of $O$ Lord Give Thy Holy Spirit, these lines move largely independently of each other and have much more individual freedom to express without being beholden to the other lines.

\footnotetext{
53 Tallis, Missa puer natus, 4.

${ }^{54}$ Ibid., 31.
} 
Example 5: Missa puer natus, “Agnus Dei," mm. 24-29. ${ }^{55}$

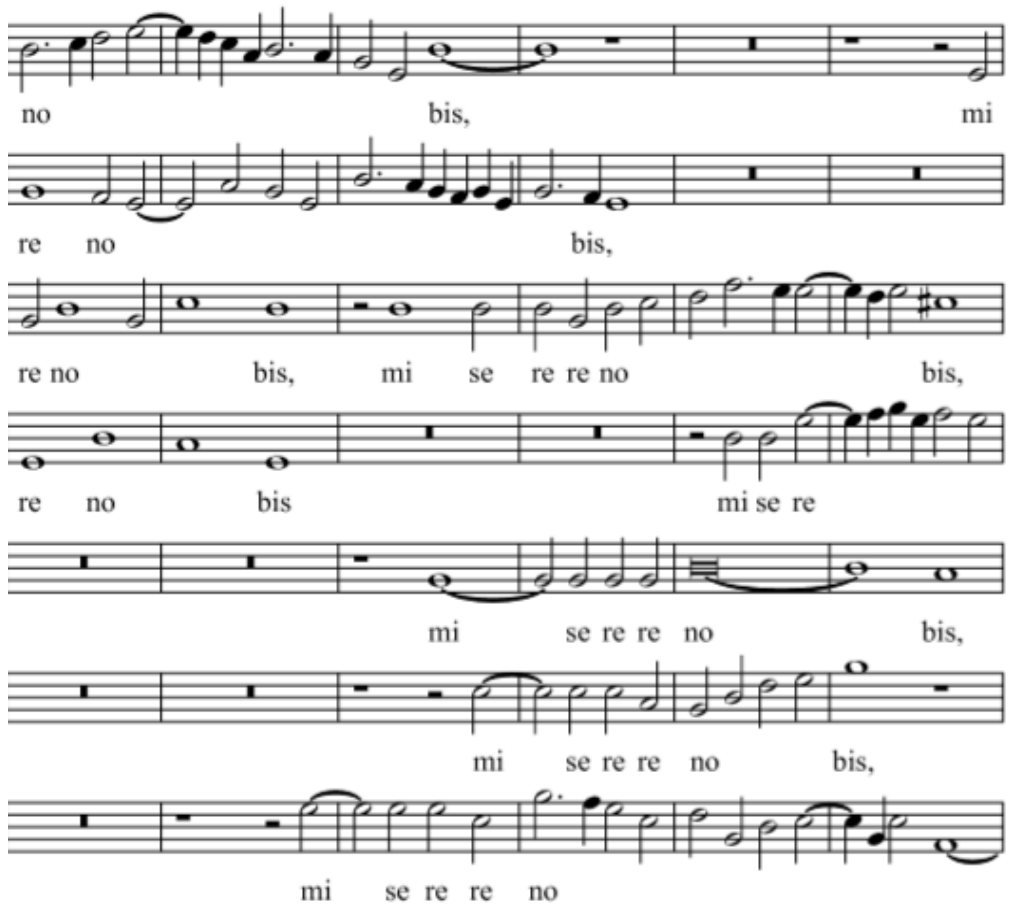

Another feature that allows for added expression at the expense of obscured text is the use of melismatic text-setting. This text-setting goes hand in hand with the polyphonic textures and passages that appear throughout the work. In the previously mentioned section, Tallis sets the "no" of "nobis" in a melismatic fashion, allowing for a florid and expressive line. The final way in which Tallis uses the greater freedom afforded him by the new values comes through using elided cadences that continue the forward momentum of the lines in the work. One such example occurs in mm. 15-17 of the "Agnus Dei" (Example 6).

55 Tallis, Missa puer natus, 31. 
Example 6: Missa puer natus, “Agnus Dei,” mm. 15-17. ${ }^{56}$

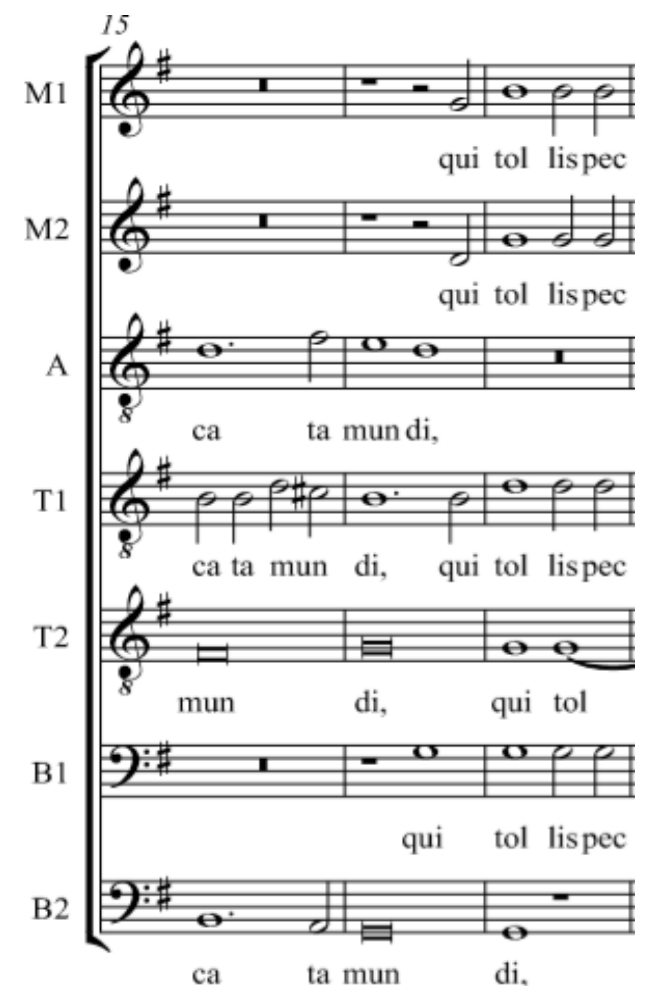

The elided cadence here allows the flow of the line to continue without reaching a concluding point as often happened in much smaller sections of the English anthems penned by Tallis. This cadence serves to further enhance the expressiveness of the work but takes away from its overall textual clarity. Throughout his entire Missa puer natus and in many other works from this period, Tallis utilizes the new freedom afforded to him in many ways to increase the expressiveness of his work.

By using the differing rules and parameters from the political and religious upheaval during the English Reformation, Thomas Tallis's style reflects the changing values that defined England in the sixteenth century. While many of his contemporaries faded from the lens of history, Tallis's status has only increased, demonstrating the power of pragmatism and conformity in an age where political and religious

${ }^{56}$ Tallis, Missa puer natus, 31. 
dissidence often resulted in death. ${ }^{57}$ Tallis's uncanny ability to navigate the political turmoil of sixteenth century England was only matched by his ability to create music that was both stylistically appropriate to the time and pleasing to the ear. While the works he created during the Catholic reign of Queen Mary were decidedly more expressive than his equivalent Protestant works, the careful calibration and stylistic detail of his Edwardian works reveal a multifaceted talent that sought to make the most of the art no matter the parameters. ${ }^{58}$ Gant describes the brilliance of Tallis's adaptation this way: "There is an image, popular today, of the Tudor Catholic composer weeping and wailing in solitude, bemoaning his fate in sad, self-imposed internal exile, despised and rejected by the world around him. But Tallis played a blinder. This was a man who did well out of the war." ${ }^{59}$ It was this brilliance and adaptability that caused the evolution of Tallis's style to accurately reflect the rapidly shifting values in England and allowed him to become one of the greatest figures in the grand tradition of English choral music.

\section{Bibliography}

Bertoglio, Chiara. Reforming Music: Music and the Religious Reformations of the Sixteenth Century. Berlin: De Gruyter, 2017. doi:10.1515/9783110520811.

Bowers, Roger. "Thomas Tallis at Dover Priory, 1530-1531." Early Music 44, no. 2 (May 2016): 197-205. doi:10.1093/em/caw $\underline{043}$.

Burkholder, J. Peter, Donald Jay Grout, and Claude V. Palisca. A History of Western Music. $9^{\text {th }}$ ed. New York: W. W. Norton, 2014.

Gant, Andrew. "The Composers of the Chapel Royal." Organists' Review 97, no. 2 (May 2011): 7-15. http://search.ebscohost .com/login. aspx ?direct $=$ true $\& d b=a 9 h \& A N=93817117 \&$ site =eds-live.

- O Sing Unto the Lord: A History of English Church Music. Chicago: University of Chicago Press, 2017.

Harley, John. Thomas Tallis. Burlington, VT: Ashgate, 2015.

${ }^{57}$ Gant, $O$ Sing, 98-101.

${ }^{58}$ Ibid., 101.

${ }^{59}$ Ibid. 
Henderson, Clayton Wilson Jr. "The Effects of the English

Reformation on Music as Seen in the Church Music of Thomas Tallis." Master's thesis, Ohio University, 1960.

Tallis, Thomas. "If Ye Love Me, Keep My Commandments: Full Anthem for Whitsunday." Musical Times and Singing Class

Circular 10, no. 231 (May 1862): 243-245. doi:10.2307 13352809.

Missa Puer Natus. Edited and published by Gervais Frykman, 2019. https://imslp.org/wiki/Mass Puer Natus (Tallis\%2C _Thomas).

. O Lord Give Thy Holy Spirit. London: Novello, 1899. https://imslp.org/wiki/O Lord\%2C Give Thy Holy Spirit (Tallis\%2C Thomas).

Tallis, Thomas, and William Byrd. Tallis, T.: Latin and English Motets/Anthems. Rodolfus Choir. Ralph Allwood. Herald Records, 2018.

Willis, Jonathan. Church Music and Protestantism in Post-Reformation England: Discourses, Sites and Identities. St. Andrews Studies in Reformation History. Burlington, VT: Ashgate, 2010. 